\title{
" On the Origin of the Sogdian Surname Zhaowu and Related Problems ». Journal Asiatique, 291, 1-2, (2003), pp. 35-67.
}

\author{
Étienne de La Vaissière
}

\section{(2) OpenEdition \\ 12 Journals}

\section{Édition électronique}

URL : http://journals.openedition.org/abstractairanica/3607

DOI : 10.4000/abstractairanica.3607

ISSN : 1961-960X

Éditeur:

CNRS (UMR 7528 Mondes iraniens et indiens), Éditions de l'IFRI

\section{Édition imprimée}

Date de publication : 15 mai 2005

ISSN : 0240-8910

Référence électronique

Étienne de La Vaissière, « " On the Origin of the Sogdian Surname Zhaowu and Related Problems ». Journal Asiatique, 291, 1-2, (2003), pp. 35-67. », Abstracta Iranica [En ligne], Volume 26 | 2005, document 32, mis en ligne le 08 décembre 2005, consulté le 25 septembre 2020. URL : http://

journals.openedition.org/abstractairanica/3607 ; DOI : https://doi.org/10.4000/abstractairanica.3607

Ce document a été généré automatiquement le 25 septembre 2020.

Tous droits réservés 
" On the Origin of the Sogdian Surname Zhaowu and Related Problems ». Journal Asiatique, 291, 1-2, (2003), pp. 35-67.

Étienne de La Vaissière

Le titre de Zhaowu donné dans les sources chinoises aux souverains sogdiens a longtemps rendu perplexes les commentateurs. O. Smirnova avait dès 1963 proposé d'y voir la transcription chinoise du titre attesté dans I'« Histoire de Boukhara » de Narshakhi sous la forme Jamūk. L'A. présente un tableau complet des attestations du titre dans les sources chinoises et sogdiennes.

\section{INDEX}

Thèmes : 2.1. Langues anciennes

Mots-clés : linguistique, Sogdien, chinois

Keywords : linguistics, Sogdian, Chinese

nompropre Sogdiens, Sogdians 
AUTEURS

ÉTIENNE DE LA VAISSIÈRE

ENS - Paris 